\title{
Effect of different packing materials and storage periods on physico-chemical characteristics of citrus fruits
}

\author{
Muhammad Arif Bangulzai ${ }^{1}$, Mujahid Hussain Leghari ${ }^{*}$, Niaz Ahmed \\ Wahocho' ${ }^{1}$, Qadir Bux Baloch ${ }^{1}$, Khalid Hussain Talpur ${ }^{2}$, Abdul Qadir \\ Gola $^{1}$ and Safdar Ali Wahocho ${ }^{1}$
}

1. Department of Horticulture, Sindh Agriculture University Tandojam-Pakistan

2. Department of Soil Science, Sindh Agriculture University Tandojam-Pakistan

*Corresponding author's email: mujahidleghari@yahoo.com

\section{Citation}

Muhammad Arif Bangulzai, Mujahid Hussain Leghari, Niaz Ahmed Wahocho, Qadir Bux Baloch, Khalid Hussain Talpur, Abdul Qadir Gola and Safdar Ali Wahocho. Effect of different packing materials and storage periods on physico-chemical characteristics of citrus fruits. Pure and Applied Biology. Vol. 9, Issue 1, pp565-575. http://dx.doi.org/10.19045/bspab.2020.90062

\begin{tabular}{llll}
\hline \hline Received: 16/09/2019 & Revised: 22/11/2019 & Accepted: 02/12/2019 & Online First: 06/12/2019 \\
\hline
\end{tabular}

\section{Abstract}

Storage of surplus fruit has become the business activity of great significance and countries with abundant fruit resources and having short harvest reason are emphasizing more for established storage to maintain quality of fruits, increase shelf life for off-season use. A laboratory study was carried out during 2015 to investigate the effect of packing materials (Gunny bags, wooden crates, paper boxes and plastic bags) on the physico-chemical properties of sweet orange and grape fruit at different storage intervals (day-1, 3, 6 and 9) at the Department of Horticulture, Faculty of crop Production, Sindh Agriculture University Tandojam. The results revealed that fruit weight, diameter, $\mathrm{pH}$, TSS, moisture, ash and specific gravity varied significantly $(\mathrm{P}<0.05)$ for citrus varieties, packing materials and storage periods. The stored citrus fruits packed in paper box revealed better performance and maintained their physico-chemical characteristics. The stored citrus fruits packed in wooden crates ranked $2^{\text {nd }}$ for quality attributes for sweet orange and grape fruits. The sweet oranges and grape fruit packed in gunny bags and plastic bags showed quality deterioration in regards to fruit physico-chemical characteristics studied. It was concluded that regardless the citrus varieties, paper box packing proved to be most suitable for citrus fruit storage, which maintained the better fruit quality and lesser fruit weight loss than rest of the packing materials. Sweet orange remained in acceptable quality up to six days of storage under room temperature while grape fruits remained in acceptable quality up to 9 days after storage later the fruit quality was deteriorated.

Keywords: Grape fruit; Packing material; Physico-chemical characteristics; Storage period; Sweet orange Introduction

Fruits are the significant component of daily diet of the developed communities. The fruit juice is nutritious and plays important role in healthy human diet [1]. The fruits are abundantly available for consumption in their organic form and all the rich in nutrients required by human for maintenance of health

[2]. Citrus fruits belong to the family Rutaceae and are cultivated worldwide. There are numerous citrus varieties and their fruits are beneficial not only for human health view point but their medicinal values are also well recognized [3]. Citrus fruits are mostly rich in vitamin $\mathrm{C}$ and many important nutrient elements required for human health 
[4]. In Pakistan the most common citrus varieties that are grown are; Grapefruit, Mandarin, Sweet Orange, Bitter orange, Lime, Lemon, Rough Lemon and Kinnow. Among the citrus varieties, kinnow contributes a lion share (95\%) to citrus export. Among hybrid citrus, sweet orange is most important and abundantly produced in Southeast Asia [5]. Orange juice is widely used in almost all countries of the world and considered as the richest source of vitamin C as well as bio-available phytochemicals that function and act as antioxidants [6], and if consumed, blood lipid profiles are naturally improved particularly those affected by hyper-cholesterolemia [7]. The juice extracted from the oranges constitutes water, sugar and fruit pulp and rich in vitamins and minerals. Generally, it is assumed that the stored fruit are not suitable for maintenance of required quality in some fruits but improved storage measures can maintain the fruit quality for a longer period [8]. Pakistan is one of the major producers of the sweet orange. However, due to abundant production and inadequate storage facilities, approximately $20-40 \%$ produce is wasted during pre and post-harvest processes. Hence, it is high time to examine the storage system and its allied aspects [9]

In Pakistan, most of the oranges are produced in upper Punjab areas of Pakistan including Faisalabad, Sargodha, Jhang, Mianwali, Rawalpindi and the adjacent areas and the produce is transported to other parts of the country and export as well [10]. Packaging of citrus fruits immediately after harvest is most important step. So proper packaging is of great significance to maintain the fruit quality and avoid injury during transportation and storage [11]. Similarly, packing materials have great impact on the produce being transported and storage [12]. The role of packaging is very important in post-harvest operations of horticultural crops but its role is still underestimated in the country. Use of polymeric films is very pronounced in packaging of fruits with a purpose to extend their storage life [13], investigated the effects of packaging materials on citrus juices and reported that prolonged shelf life of citrus fruits and juices are dependent on the storage quality, and opinion that fruit weight loss can be minimized with improved packing materials and storage conditions. [14] reported that the increase in $\mathrm{pH}$ value of the stored citrus fruits is largely related to poor quality storage conditions. [15] reported considerable changes in the Total soluble solids (TSS) levels of citrus fruits under storage conditions. [16] reported that soluble solids increased with increase in storage duration with maximum increase in control and paper based uni-packing showed maximum TSS in fruits (12.73\%) [17] reported that wooden crates and paper boxes were suitable packing for storage oranges to maintain their market quality for a longer duration. [18] reported that the ash content may vary in citrus fruits due to varieties and storage quality.

In view of the above facts, the present study was carried out to investigate the effect of different packing materials and storage periods on physico-chemical characteristics of citrus fruits.

\section{Materials and methods}

The effect of packing materials on the physico-chemical properties of sweet orange and grape fruit at different storage intervals was investigated during the year 2015 at the Department of Horticulture, Faculty of crop Production, Sindh Agriculture University Tando Jam. The sweet oranges and grape fruits were packed in different packing materials (Gunny bags, wooden crates, paper boxes and plastic bags) and physic-chemical characteristics were monitored at 01, 03, 06 and 09 days after storage. The fresh harvested fruits of sweet orange and grape fruit were purchased from the local market and brought to the laboratory, Department of Horticulture, 
Sindh Agriculture University Tando Jam. The fruits of both the varieties were cleaned and weighed individually. The fruit with almost equal in weight are selected so that variation in the initial fruit is minimized. The packed fruits in different packaging were stored under room temperature $\left(22 \pm 3^{\circ} \mathrm{C}\right)$. The experiment was replicated in triplicate for each treatment to adjust any uneven variation for chemical properties. After every three days, the samples from each packaging were collected for chemical analysis. The data were recorded for the fruit quality characteristics including fruit weight $(\mathrm{g})$, diameter of fruit $(\mathrm{cm}), \mathrm{pH}$ value, TSS $(\%)$, moisture (\%), ash content (\%), Specific gravity $\left(\mathrm{g} / \mathrm{cm}^{3}\right)$. For determination of chemical characteristics of orange juice, certain laboratory methods which are well defined internationally were adopted as described below.

\section{Methods of determination}

\section{Fruit weight (g)}

The sample fruits were weighed by electronic loading balance in the laboratory. Initially all the fruits in each packaging were weighed and weight was recorded on the data recording sheet. After 3 days, 6 days and 9 days of storage, only the sample fruits were weighed for each storage period in grams for each citrus variety and averages were worked out.

\section{Fruit diameter (cm)}

The fruit diameter was measured by means of Vernier calliper. This instrument is used to measure the girth or diameter. The sample fruits were individually fixed in Vernier calliper by moving the scale knob up to the certain point where the girth or diameter is written in centimeters.

\section{pH (value)}

The $\mathrm{pH}$ value was calibrated with buffer solutions at $\mathrm{pH} 4$ and electrode was dried and then inserted in or juice solution.
When the first reading was completed, the electrode was rinsed with distilled water and dried up with tissue paper; accordingly.

\section{Total soluble solids (TSS) (\%)}

The total soluble solids (TSS) were determined as per method described by using Digital Bench Refractometer. Before use, the instrument was cleaned and adjusted to zero at $20^{\circ} \mathrm{C}$ using distilled water. An appropriate quantity of sample of each product was placed on the prism-plate of the refrectometer with the help of a glass rod and folding back the cover. For each sample the instrument was calibrated by using distilled water. The reading appeared on the screen was directly recorded as total soluble solids (Brix).

Ash (\%)

The ash content of composite samples was determined by the procedure as described by [19].Washed and cleaned crucibles were dried in hot air oven and were weighed (W1). Three grams of sample was taken into crucibles (W2). Crucibles were placed in muffled furnace at $550^{\circ} \mathrm{C}$ for 16 hours. Afterward crucibles were cooled in desiccators and weighed (W3). The following formula was used to calculate the ash content:

Ash $\%=\mathrm{W} 3-\mathrm{W} 1 \mathrm{x} 100$

W2

\section{Moisture (\%)}

The moisture content of composite samples was determined by using the procedure described in [20]. Two gram sample was weighed in a moisture dish. The moisture dish containing sample was placed in hot air oven at $70^{\circ} \mathrm{C}$ for $6-8$ hours. After that sample was removed from oven and placed in desiccator for one hour for cooling and weighed. Moisture \% was calculated by using the following formula:

Moisture \% = Initial Weight - Final Weightx 100 Sample Weight 


\section{Specific gravity $\left(\mathrm{g} / \mathrm{cm}^{3}\right)$}

The specific gravity was determined using specific gravity bottle. The empty bottle was weighed, filled with distilled water and reweighed. It was then filled with juice sample and weighed. The specific gravity of the juice was calculated, as [21] as follies follows:

$\mathrm{SG}=\underline{\mathrm{W}_{\mathrm{J}}}$

Ww

\section{Statistical analysis}

The data were analyzed using SAS procedures [22]. The analysis of variance (ANOVA) tables were constructed using the GLM (General Linear Model) procedure. The mean separations were carried out by the least significant difference (LSD) method at 5\% significance level.

\section{Results and discussion}

\section{Fruit weight (g)}

The results presented in (Table 1) revealed that fruit weight losses in sweet orange and grape fruit was minimum with highest fruit weight of sweet orange $(166.02 \mathrm{~g})$ and grape fruit $(355 \mathrm{~g})$ when packed in paper boxes and lowest $(328.66 \mathrm{~g})$ in plastic bags. With increase in the storage period, the fruit weight was simultaneously decreased. Apart from the weight loss during storage period, the sweet oranges and grape fruits packed in paper boxes showed minimum weight loss, followed by wooden crates; while the weight loss in fruits of both the citrus varieties were higher when packed in gunny bags and plastic bags table 1 . Naturally the grape fruits were heavier in weight than the sweet oranges and the weight loss due to packing materials and storage periods were affected accordingly. This indicates that in plastic boxes packing, the sweet oranges and grape fruits weight was maximally decreased; while the minimum weight loss was recorded in fruits packed in paper boxes. These results are in agreement with those of [23] who investigated the effects of packaging materials on citrus juices and reported that prolonged shelf life of citrus fruits and juices are dependent on the storage quality. [24] were of the opinion that fruit weight loss can be minimized with improved packing materials and storage conditions.

\section{Fruit diameter $(\mathbf{c m})$}

The fruit diameter was highest in sweet orange $(5.59 \mathrm{~cm})$ when packed in wooden crates and in grape fruits $(10.13 \mathrm{~cm})$ when packed in paper boxes; while increase in the storage period, the fruit diameter was simultaneously decreased regardless the citrus varieties table 2 . The grape fruit was markedly greater in diameter than the sweet oranges. Regardless the changes occurred in fruit diameter during storage period, the sweet oranges and grape fruits packed in paper boxes showed minimum changes, followed by wooden crates; while the fruit diameter in fruits of both the citrus varieties showed more changes when packed in gunny bags and plastic bags. However, the change in the fruit diameter was more affected by the citrus variety because of their physical shape and mass. This indicates that in paper box packing, the sweet oranges and grape fruits weight showed minimum physical change; while the maximum physical change was noted in fruits packed in gunny bags and plastic bags. Similar findings have also been discussed by [25] who argued that the fruit shape and size may change with the storage conditions; but increase in the size of the fruit under storage conditions can adverse effect the fruit quality and its market acceptability. 
Table 1.Fruit weight (g) of citrus varieties as affected by different packing materials at various storage periods

\begin{tabular}{|c|c|c|c|c|c|c|}
\hline \multirow[b]{2}{*}{ Variety } & \multirow[b]{2}{*}{ Packing materials } & \multicolumn{4}{|c|}{ Storage period days } & \multirow[b]{2}{*}{ Mean } \\
\hline & & 01 Day & 03 Days & $\begin{array}{c}06 \\
\text { Days }\end{array}$ & $\begin{array}{c}09 \\
\text { Days }\end{array}$ & \\
\hline \multirow{5}{*}{$\begin{array}{c}\text { Sweet } \\
\text { Orange }\end{array}$} & Gunny bags & 181.00 & 174.48 & 167.50 & 129.22 & $163.05 \mathrm{~A}$ \\
\hline & Wooden crates & 182.00 & 173.63 & 166.68 & 141.76 & $166.02 \mathrm{~A}$ \\
\hline & Paper boxes & 178.67 & 169.91 & 163.11 & 141.03 & $163.18 \mathrm{~A}$ \\
\hline & Plastic bags & 184.67 & 177.28 & 170.10 & 108.14 & 160.07 B \\
\hline & Mean & $\begin{array}{c}181.58 \\
E\end{array}$ & $\begin{array}{c}173.83 \mathrm{E} \\
F \\
\end{array}$ & $\begin{array}{c}166.87 \\
F\end{array}$ & $\begin{array}{c}\text { 130.04 } \\
\text { G }\end{array}$ & $163.08 \mathrm{~B}$ \\
\hline \multirow{5}{*}{$\begin{array}{c}\text { Grape } \\
\text { fruit }\end{array}$} & Gunny bags & 375.00 & 364.50 & 349.92 & 317.11 & $351.63 \mathrm{~A}$ \\
\hline & Wooden crates & 375.00 & 360.75 & 346.32 & 324.68 & $351.69 \mathrm{~A}$ \\
\hline & Paper boxes & 378.33 & 363.20 & 348.67 & 330.51 & $355.18 \mathrm{~A}$ \\
\hline & Plastic bags & 359.67 & 346.00 & 332.16 & 276.80 & $328.66 \mathrm{~B}$ \\
\hline & Mean & $\begin{array}{c}372.00 \\
\text { A }\end{array}$ & 358.61 B & $\begin{array}{c}344.27 \\
\text { C }\end{array}$ & $\begin{array}{c}312.28 \\
\text { D }\end{array}$ & $346.79 A$ \\
\hline
\end{tabular}

Varieties (V)

Packing materials $(\mathrm{P})$

Storage period $(\mathrm{S})$

$\mathrm{VxP}$

$\mathrm{VxS}$

$\mathrm{PxS}$

\section{SE}

1.8313

2.5899

2.5866

3.6627

3.6632

5.1798
LSD 0.05

3.6516

5.1641

5.1641

7.3032

0.1086

10.328

Table 2. Fruit diameter $(\mathrm{cm})$ of citrus varieties as affected by different packing materials at various storage periods

\begin{tabular}{|c|c|c|c|c|c|c|}
\hline \multirow{2}{*}{ Variety } & \multirow{2}{*}{$\begin{array}{l}\text { Packing } \\
\text { materials }\end{array}$} & \multicolumn{4}{|c|}{ Storage period days } & \multirow{2}{*}{ Mean } \\
\hline & & 01 Day & 03 Days & 06 Days & 09 Days & \\
\hline \multirow{5}{*}{$\begin{array}{l}\text { Sweet } \\
\text { Orange }\end{array}$} & Gunny bags & 5.61 & 5.48 & 5.38 & 5.15 & $5.41 \mathrm{~B}$ \\
\hline & Wooden crates & 5.64 & 5.63 & 5.58 & 5.52 & $5.59 \mathrm{~A}$ \\
\hline & Paper boxes & 5.54 & 5.53 & 5.48 & 5.42 & $5.49 \mathrm{~A}$ \\
\hline & Plastic bags & 5.72 & 5.54 & 5.43 & 5.09 & $5.45 \mathrm{~B}$ \\
\hline & Mean & $5.63 \mathrm{~A}$ & $5.54 \mathrm{~A}$ & $5.47 \mathrm{~B}$ & $5.29 \mathrm{C}$ & $5.48 \mathrm{~B}$ \\
\hline \multirow{5}{*}{$\begin{array}{l}\text { Grape } \\
\text { fruit }\end{array}$} & Gunny bags & 10.12 & 10.11 & 9.11 & 9.50 & $9.89 \mathrm{~B}$ \\
\hline & Wooden crates & 10.12 & 10.11 & 10.02 & 9.50 & $10.04 \mathrm{~A}$ \\
\hline & Paper boxes & 10.21 & 10.20 & 10.11 & 10.00 & $10.13 \mathrm{~A}$ \\
\hline & Plastic bags & 9.71 & 9.70 & 9.12 & 8.92 & $9.36 \mathrm{C}$ \\
\hline & Mean & $10.04 \mathrm{~A}$ & $10.03 \mathrm{~A}$ & $9.77 \mathrm{~B}$ & $9.58 \mathrm{C}$ & $9.85 \mathrm{~A}$ \\
\hline
\end{tabular}

Varieties (V)

Packing materials (P)

Storage period $(\mathrm{S})$

$\mathrm{VxP}$

$\mathrm{VxS}$

$\mathrm{PxS}$

PH value

The fruit $\mathrm{pH}$ was highest in sweet orange (3.58) when packed in gunny bags and for grape fruits (3.64) when packed in plastic bags; while the 
increase in the storage period, the fruit $\mathrm{pH}$ was increased considerably regardless the citrus varieties; while $\mathrm{pH}$ of grape fruit was lower than the sweet oranges table 3 . The $\mathrm{pH}$ value is a chemical characteristic and can change in fruit juice and such change may occur with the prolonged storage and storage conditions. Moreover, the $\mathrm{pH}$ levels may differ for juices obtained from different varieties. Irrespective of chemical changes occurred in juice during storage period, the sweet oranges packed in plastic bags showed minimum chemical changes for $\mathrm{pH}$, while the $\mathrm{Ph}$ value was lowest in grape fruits when packed in paper boxes. There was also significant $(\mathrm{P}<0.05)$ difference in fruit $\mathrm{pH}$ for varieties, and on average sweet orange fruit $\mathrm{pH}$ was higher (3.38) as compared to grape fruit (3.23). This indicates that in gunny bag packing, the orange fruit $\mathrm{pH}$ increased significantly; while in grape fruit, the plastic bag packing increased the fruit $\mathrm{pH}$ markedly. The results of the present study are in accordance with those of [26] who reported considerable biochemical changes in fruit during storage, and $\mathrm{pH}$ may increase with spoilage of the storage fruits. [27] reported that the increase in $\mathrm{pH}$ value of the stored fruit was largely related to poor quality storage conditions.

Table 3. pH value of citrus varieties as affected by different packing materials at various storage periods

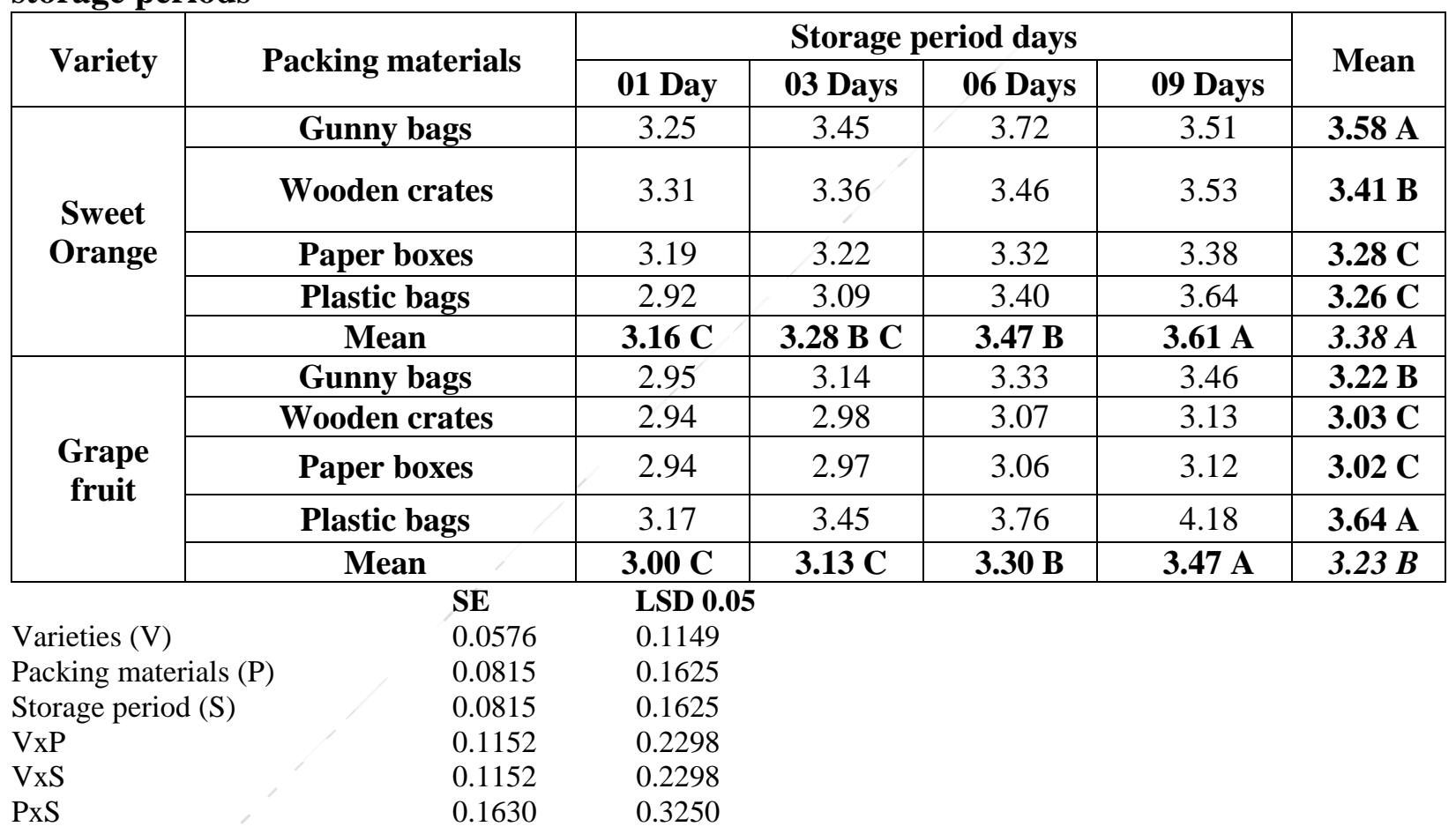

\section{Total soluble solids TSS (\%)}

The Total soluble Solids (TSS) was highest in sweet oranges (13.22\%) when packed in wooden crates; while TSS in grape fruits was (11.01\%) when packed in paper boxes table 4. TSS was markedly higher in sweet orange samples as compared to grape fruits regardless the treatment affect. On the other hand, the TSS increased with prolonging the storage period (Table 4). There was different response of citrus varieties to TSS after storage and this characteristic decreased after 6 and 9 days of storage in sweet orange; while in grape fruits, the TSS increased when determined after 2, 6 and 9 days of storage. However, apart from the storage period impact, the sweet oranges and grape fruits packed in paper boxes and wooden crates showed higher TSS contents in juice; while the TSS content was markedly lower in the juice of citrus fruits when packed in gunny bags and plastic bags. Similarly, the differences in TSS in grape fruit determined after 3, 6 and 9 days after storage were non- 
significant. This indicates that the paper box and wooden crate were the most suitable packing for citrus fruits under room temperature storage. However, in citrus varieties, the TSS was significantly higher in juice of sweet oranges as compared to grape fruit juice. The TSS contents in citrus fruits may be mainly associated with the genetic makeup of the varieties; while the field management for nutrients and postharvest storage conditions may also influence this characteristic. Similar results on the effect of packing materials on the total soluble solids have been reported in previous studies. [28] investigated the physic- chemical properties of orange juice and found changes in TSS due to different packing materials and storage conditions as well as storage duration.[29] examined two citrus varieties for TSS and reported TSS up to $17.47 \%$ in sweet oranges due to delayed storage. Moreover, TSS was significantly influenced by the packing materials, reported considerable changes in the TSS levels of citrus fruits under storage conditions. [30] reported that soluble solids increased with increase in storage duration with maximum increase in control and paper based uni-packing showed maximum TSS in fruits.

Table 4.TSS (\%) in citrus varieties as affected by different packing materials at various storage periods

\begin{tabular}{|c|c|c|c|c|c|c|}
\hline \multirow{2}{*}{ Variety } & \multirow{2}{*}{ Packing materials } & \multicolumn{4}{|c|}{ Storage period days } & \multirow[t]{2}{*}{ Mean } \\
\hline & & 01 Day & 03 Days & 06 Days & 09 Days & \\
\hline \multirow{5}{*}{$\begin{array}{l}\text { Sweet } \\
\text { Orange }\end{array}$} & Gunny bags & 13.11 & 13.24 & 12.71 & 12.20 & $12.81 \mathrm{C}$ \\
\hline & Wooden crates & 13.18 & 13.45 & 13.32 & 12.92 & $13.22 \mathrm{~A}$ \\
\hline & Paper boxes & 13.03 & 13.35 & 13.31 & 13.04 & $13.18 \mathrm{~A}$ \\
\hline & Plastic bags & 13.30 & 13.41 & 12.74 & 11.59 & $12.76 \mathrm{C}$ \\
\hline & Mean & 13.15 B & $13.36 \mathrm{~A}$ & 13.02 B & $12.44 \mathrm{C}$ & $12.99 A$ \\
\hline \multirow{5}{*}{$\begin{array}{c}\text { Grape } \\
\text { fruit }\end{array}$} & Gunny bags & 10.75 & 10.84 & 10.95 & 10.84 & $10.85 \mathrm{~B}$ \\
\hline & Wooden crates & 10.81 & 10.92 & 11.03 & 11.26 & $11.00 \mathrm{~A}$ \\
\hline & Paper boxes & 10.68 & 10.97 & 11.08 & 11.30 & $11.01 \mathrm{~A}$ \\
\hline & Plastic bags & 10.91 & 10.97 & 11.8 & 10.75 & $10.92 \mathrm{~A}$ \\
\hline & Mean & 10.79 B & 10.92 D A & $11.03 \mathrm{~A}$ & $11.04 \mathrm{~A}$ & $10.95 B$ \\
\hline \multicolumn{7}{|c|}{ LSD 0.05} \\
\hline \multicolumn{7}{|c|}{$\begin{array}{ll} & \text { SE } \\
\text { Varieties }(V) & 0.0500\end{array}$} \\
\hline \multicolumn{2}{|c|}{ Packing materials $(\mathrm{P}) \quad 0.0707$} & \multicolumn{2}{|c|}{0.1409} & & & \\
\hline \multicolumn{2}{|c|}{ Storage period $(\mathrm{S})$} & \multicolumn{2}{|c|}{0.1409} & & & \\
\hline \multicolumn{2}{|c|}{$\mathrm{VxP}$} & \multicolumn{2}{|c|}{0.1993} & & & \\
\hline \multicolumn{2}{|r|}{0.1000} & \multicolumn{2}{|c|}{0.1993} & & & \\
\hline \multicolumn{2}{|r|}{0.1414} & \multicolumn{2}{|c|}{0.2819} & & & \\
\hline
\end{tabular}

\section{Moisture content (\%)}

The moisture was highest in sweet orange $(84.17 \%)$ and grape fruit $(86.63 \%)$ when packed in paper boxes table 5 . The increase in the storage period showed that the moisture decreased simultaneously in a significant manner regardless the citrus varieties. However, grape fruits contained higher moisture content than the sweet oranges. Apart from the storage period impact, the sweet oranges and grape fruits packed in paper boxes and wooden crates showed higher moisture contents; while the moisture content markedly lower in citrus fruits when packed in gunny bags and plastic bags (Table 5). There was a rapid decrease in moisture content of citrus fruits with prolonging storage under room temperature. However, the loss of moisture was more in sweet orange as compared to grape fruit. This indicates that paper box and wooden crate were the most suitable packing for citrus fruits under room temperature storage. Similar results have also been reported by [31] who reported that during storage of citrus fruits, the moisture content considerably decreased. They reported that wooden crates and paper boxes were suitable packing for storage of oranges to maintain their market quality for a longer duration. 
Table 5. Moisture content (\%) in citrus varieties as affected by different packing materials at various storage periods

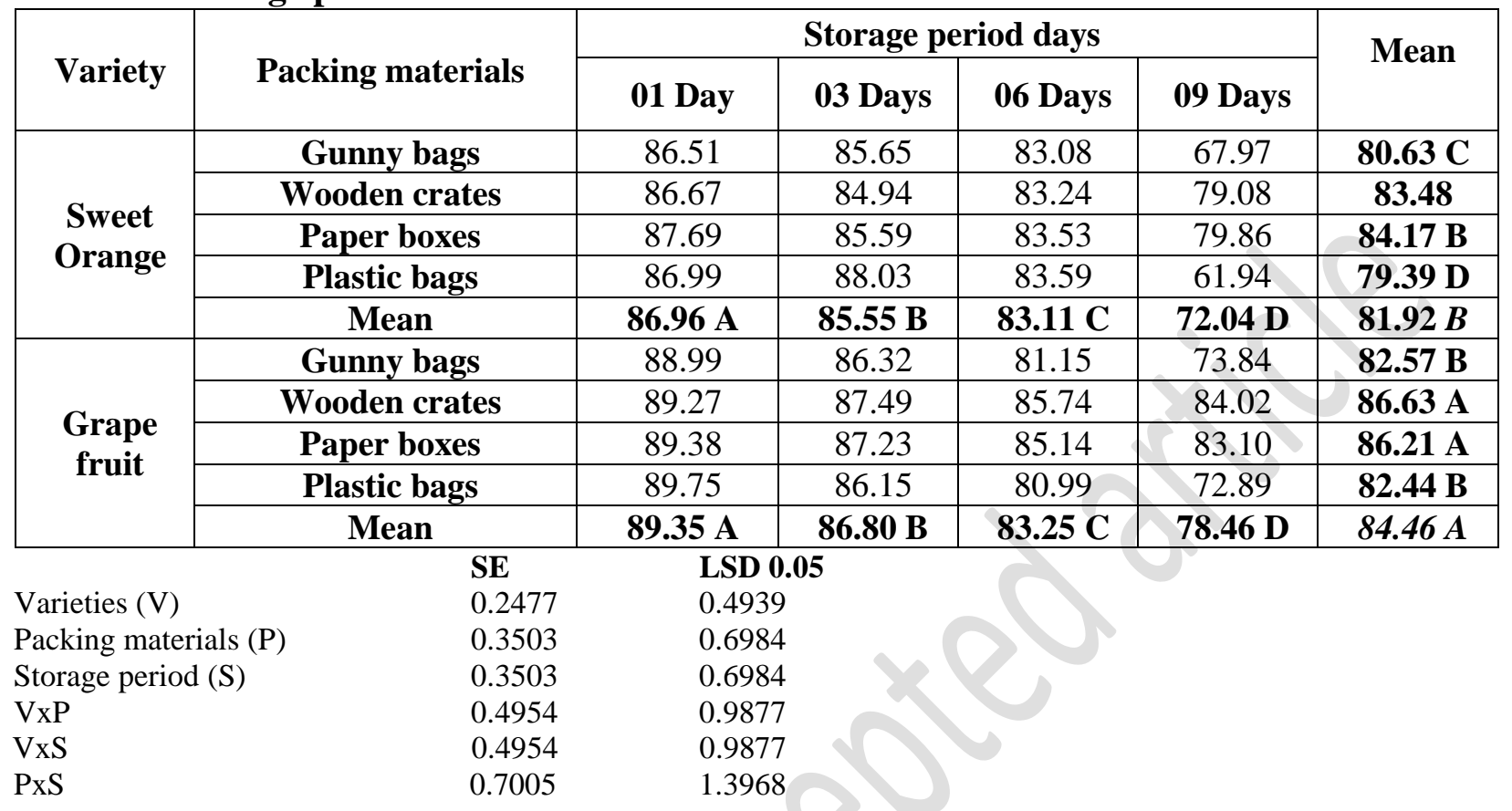

\section{Ash content (\%)}

The ash content was highest in sweet orange $(0.39 \%)$ and grape fruits $(0.31 \%)$ when packed in paper boxes; while with increase in the storage period, the ash was decreased at once after 3 days of storage and later remained constants. The ash content was higher in sweet oranges than the grape fruits, table 6. Regardless the storage period effect, the sweet oranges and grape fruits packed in paper boxes and wooden crates showed relatively higher ash contents; while the ash content markedly lower in citrus fruits when packed in gunny bags and plastic bag. However, in case of sweet orange the ash content was linearly influenced with prolonging storage period as well as packing materials. This indicates that the paper box and wooden crate were the most suitable packing for citrus fruits under room temperature storage. The ash content is mostly dependent on varietal characteristic in citrus fruits; but improvement in nutrient management and better postharvest storage conditions may play significant role to influence ash content in citrus. The findings of the present research regarding ash content are in line with those of [32] who reported that the ash content may vary in citrus fruits due to varieties and storage conditions. However, there was significant impact of packing material on the ash content of stored oranges.

Specific gravity $\left(\mathrm{g} / \mathrm{cm}^{3}\right)$

The specific gravity was highest in sweet oranges (1.11) and grape fruits (0.87) when packed in paper boxes table 7 . The specific gravity remained almost unchanged after 3 days of storage, but later the specific gravity decreased with the prolonging storage period; while the specific gravity of sweet oranges was markedly higher than the grape fruits. The specific gravity of sweet oranges and grape fruits packed in paper boxes and wooden crates was relatively higher; while the specific gravity was lower for the citrus fruits when packed in gunny bags and plastic bags. The least significant difference (LSD) test showed that statistically the differences in average specific gravity of grape fruits packed in papers boxes and wooden crates were nonsignificant $(\mathrm{P}>0.05)$. The specific gravity is a character that is influenced by the quality of the fruit. The varietal response showed that overall specific gravity of the sweet orange was higher than the grape fruits. Similar results have also been reported by [33] who reported that storage conditions and packaging materials significantly 
affect the specific gravity of the oranges.

Table 6. Ash content (\%) in citrus varieties as affected by different packing materials at various storage periods

\begin{tabular}{|c|c|c|c|c|c|c|}
\hline \multirow{2}{*}{ Variety } & \multirow{2}{*}{$\begin{array}{c}\text { Packing } \\
\text { materials }\end{array}$} & \multicolumn{4}{|c|}{ Storage period days } & \multirow{2}{*}{ Mean } \\
\hline & & 01 Day & 03 Days & 06 Days & 09 Days & \\
\hline \multirow{5}{*}{$\begin{array}{l}\text { Sweet } \\
\text { Orange }\end{array}$} & Gunny bags & 0.43 & 0.36 & 0.35 & 0.34 & $0.37 \mathrm{C}$ \\
\hline & Wooden crates & 0.42 & 0.37 & 0.37 & 0.36 & 0.38 B \\
\hline & Paper boxes & 0.46 & 0.37 & 0.36 & 0.36 & $0.39 \mathrm{~A}$ \\
\hline & Plastic bags & 0.44 & 0.37 & 0.35 & 0.32 & $0.37 \mathrm{C}$ \\
\hline & Mean & $0.44 \mathrm{~A}$ & 0.37 B & $0.36 \mathrm{C}$ & $0.34 \mathrm{D}$ & $0.38 A$ \\
\hline \multirow{5}{*}{$\begin{array}{l}\text { Grape } \\
\text { fruit }\end{array}$} & Gunny bags & 0.33 & 0.30 & 0.30 & 0.30 & $0.30 \mathrm{~B}$ \\
\hline & Wooden crates & 0.33 & 0.30 & 0.30 & 0.31 & $0.31 \mathrm{~A}$ \\
\hline & Paper boxes & 0.34 & 0.30 & 0.31 & 0.31 & $0.31 \mathrm{~A}$ \\
\hline & Plastic bags & 0.35 & 0.30 & 0.31 & 0.30 & $0.31 \mathrm{~A}$ \\
\hline & Mean & $0.34 \mathrm{~A}$ & 0.30 B & $0.30 \mathrm{~B}$ & $0.30 \mathrm{~B}$ & $0.31 \mathrm{~B}$ \\
\hline \multirow{2}{*}{\multicolumn{2}{|c|}{ Varieties (V) }} & & LSD 0 & & & \\
\hline & & & 0.005 & & & \\
\hline \multicolumn{2}{|c|}{ Packing materials $(\mathrm{P})$} & & 0.0075 & & & \\
\hline \multicolumn{2}{|c|}{ Storage period $(\mathrm{S})$} & & 0.0075 & & & \\
\hline \multicolumn{2}{|c|}{$\mathrm{VxP}$} & & 0.0106 & & & \\
\hline \multicolumn{2}{|l|}{$\mathrm{VxS}$} & & 0.0106 & & & \\
\hline \multicolumn{2}{|l|}{ PxS } & & 0.0151 & & & \\
\hline
\end{tabular}

Table 7. Specific gravity $\left(\mathrm{g} / \mathrm{cm}^{3}\right)$ of fruits in citrus varieties as affected by different packing materials at various storage periods

\begin{tabular}{|c|c|c|c|c|c|c|c|}
\hline \multirow[t]{2}{*}{ Variety } & \multirow{2}{*}{\multicolumn{2}{|c|}{ Packing materials }} & \multicolumn{4}{|c|}{ Storage period days } & \multirow{2}{*}{ Mean } \\
\hline & & & 01 Day & 03 Days & 06 Days & 09 Days & \\
\hline \multirow{5}{*}{$\begin{array}{l}\text { Sweet } \\
\text { Orange }\end{array}$} & & ags & 1.09 & 1.08 & 1.06 & 1.04 & $1.07 \mathrm{C}$ \\
\hline & & ates & 1.09 & 1.12 & 1.10 & 1.08 & $1.10 \mathrm{~B}$ \\
\hline & & xes & 1.10 & 1.14 & 1.11 & 1.09 & $1.11 \mathrm{~A}$ \\
\hline & & & 1.09 & 1.06 & 1.02 & 0.87 & $1.05 \mathrm{D}$ \\
\hline & & & $1.09 \mathrm{~B}$ & $1.10 \mathrm{~A}$ & $1.08 \mathrm{C}$ & $1.06 \mathrm{D}$ & $1.08 \mathrm{~A}$ \\
\hline \multirow{5}{*}{$\begin{array}{l}\text { Grape } \\
\text { fruit }\end{array}$} & & ags & 0.86 & 0.85 & 0.83 & 0.82 & 0.84 B \\
\hline & & ates & 0.87 & 0.89 & 0.87 & 0.86 & $0.87 \mathrm{~A}$ \\
\hline & & xes & 0.87 & 0.89 & 0.87 & 0.86 & $0.87 \mathrm{~A}$ \\
\hline & & ggs & 0.87 & 0.84 & 0.82 & 0.81 & $0.83 \mathrm{C}$ \\
\hline & & & $0.86 \mathrm{~A}$ & 0.86 A & 0.84 B & $0.83 \mathrm{C}$ & 0.85 B \\
\hline \multirow{2}{*}{\multicolumn{2}{|c|}{ Varieties (V) }} & SE & & LSD 0.0 & & & \\
\hline & & 0.0025 & & 0.00497 & & & \\
\hline \multicolumn{2}{|c|}{ Packing materials (P) } & 0.0035 & & 0.0075 & & & \\
\hline \multicolumn{2}{|c|}{ Storage period (S) } & 0.0035 & & 0.0075 & & & \\
\hline \multicolumn{2}{|l|}{ VxP } & 0.0050 & & 0.0100 & & & \\
\hline \multicolumn{2}{|l|}{$\mathrm{VxS}$} & 0.0050 & & 0.0100 & & & \\
\hline \multicolumn{2}{|l|}{ PxS } & 0.0070 & & 0.0141 & & & \\
\hline
\end{tabular}

\section{Conclusion}

It is concluded that regardless the citrus varieties, paper box packing proved to be most suitable for citrus fruit storage, which maintained the better fruit quality and lesser fruit weight loss than rest of the packing 
materials. Citrus fruits packing in wooden crates also showed promising results for maintaining the fruit quality. Sweet orange remained in acceptable quality up to six days of storage at room temperature while grape fruits remained in acceptable quality up to 9 days after storage later the quality was deteriorated. It is recommended that for maintaining storage quality of sweet orange and grape fruits under room temperature paper box packing may be used followed by wooden crates.

\section{Author's contributions}

Conceived and designed the experiments: MA Bungulzai \& MH Leghari, Performed the experiments: NA Wahocho, QB Baloch \& AQ Gola, Analyzed the data: KH Talpur \& SA Wahocho, Contributed reagents/ materials/ analysis tools: MH Leghari, NA Wahocho \& AQ Gola, Wrote the paper. MH Leghari\& NA Wahocho.

\section{References}

1. Kurowska EM, Spence JD, Jordan J, Freeman SDJ \& Piche LA (2000). Cholesterol-raising effect of orange juice in subjects with hypercholesterolemia. Inter $J$ Nutri 72(1): 1095-1097.

2. Franke AA, Cooney RV, Henning SM \& Custer LJ (2005). Bioavailability and antioxidant effects of orange juice components in humans. J Agric Food Chem 53(13): 5170-5178.

3. Aslin SA (2014). Role of citrus fruit in health. J Pharm Sci \& Res 6(2): 121-123.

4. Adetunji T, Oulé K, Doyon MK, Lencki G \& Arul RW (2013). Postharvest Bio and Tech 12(46): 212-221

5. Agostini JDS, Scalon SDPQ, Silva KED, Lima FFD, Gomes APE \& Leite MM (2013). Physicochemical and microbiological characteristics of minimally processed 'Champagne' oranges (Citrus reticulate, Citrus sinensis) in different packgings. Food Sci and Tech (Campinas) 33(1): 84-92

6. Berlinet C, Ducruet V, Brat P, Brillouet JM, Reynes M \& Guichard E (2003). Effects of PET packaging on the quality of an orange juice made from concentrate.
Proc Inter Conf Eng and Food (ICEF9 2003): 219-223.

7. Haugaard V, Weber C, Danielsen B \& Bertelsen G (2011). Quality changes in orange juice packed in materials based on polylactate. Euro Food Res and Tech 214(5): 423-428.

8. Muratore G, Lanza CM, Baiano A, Tamagnone P, Nicolosi CA \& Nobile MA (2005). The influence of using different packaging on the quality decay kinetics of Cuccia. J of Food Engi 12(73): 239-245.

9. Xie RJ, Zheng L, Jing L, He SL, Xi QP, Lv Q, Yi SL, Zheng YQ \& Deng L (2013). The Effect of Cultivar and Bagging on Physicochemical Properties and Antioxidant Activity of Three Sweet Orange Cultivars (Citrus sinensis (L.) Osbeck). American-Eurasian J Agric \& Environ Sci 13(2): 139-147.

10. Marti N, Mena P, Canovas JA, Micol V \& Saura D (2009). Vitamin C and the role of citrus juices as functional food. Nat Prod Com 4(5): 677-700.

11. Sumanjit K \& Singh S (2009). Effect of various post-harvest treatments on shelf life of lemon (Citrus limon) cv. Baraxnasi dining ambient storage. Haryana J of Horti Sci 38 (3/4): 239- 242.

12. Ritu Y \& Ray A (2010). Incorporation of.oxygen scavenger sachet for active packaging of minimally processed orange (Citrus sinensis). Haryana J of Horti Sci 39(3/4): 228-23.

13. AOAC (2000). Ash and Fat analysis (Gravimetric Method). In: Official Methods of Analysis NO.33.2.10. AOAC International, Gathersburg, Maryland, USA.

14. Helali MOH, Ibrahim M, Shafique MZ, Rahman MM, Biswas SK \& MS Islam (2007). Formulation, preparation and preservation of lemon (citrus limon L.) Cordial J Bio-Sci 16: 125-127.

15. Mahmood MA \& Sheikh AD (2006). Citrus.export system in Pak J Agric Res 44 (3): 229-238.

16. Mathooko FM \& Kiniiya EN (2002). Ascorbic acid retention in canned lime 
juice preserved with sulfur dioxide and benzoic acid. African J of Food \& Nutri Sci 2(1): 102-106.

17. Mazumdar BC \& Majumder K (2003). Methods on physico-chemical Analysis of Fruits. Uni College of Agric, Calcutta Univ 108-109.

18. Ayhan Z, Yeom HW, Zhang QH \& Min DB (2001). Flavor, Color, and Vitamin C Retention of Pulsed Electric Field Processed Orange Juice in Different Packaging Materials. J Agric Food Chem 49(2): 669-674.

19. Bahadur V, Mishra D, Singh DB \& Roshan RK (2006). Effect of varieties and preservative levels on shelf life of aonla juice. Indian J of Food Proc 4(3): 92-96.

20. Chumillas MR, Belissario Y, Iguaz A, \& Lopez A (2003). Quality and shelf life of orange juice aseptically packaged in PET bottles. Agricultural and Food Engi, Paseo Alfonso Xlll pp 48-50.

21. Deanna MM \& Jeffrey SB (2007). Acidalkaline balance role in chronic disease and detoxification. Alternative Therapies 13(4): 62-65.

22. Doyle MP, Beuchat LR \& Montville TJ (2001). Food Microbiology; American Society for Microbiology, ASM Press; Washington DC (USA).

23. Faasema J, Abu JO \& Alakali JS (2011). Effect of packaging and storage condition on the .quality of sweet orange (Citruscinesis). Inter J of Agri Tech 7(3): 797-804.

24. FDA (2001). US Food \& Drug Administration (FDA), CFSAN. Bacteriological Analytical Manual Online. Chapter 12, pp 1-6.

25. Ishiwu CN \& Oluka SI (2004). Development of Performance Evaluation of Juice Extractor. 5th International Conference and 26th annual General Meeting of the Nigerian Institution of Agri Engi 8(26): 391-395.

26. Jalil MA, Ullah J, Durrani Y, Zeb A \& Khan M (2004). Development of low caloric orange squash and physicochemical evaluation during its storage interval. Sarhad J Agric 20(4): 651-654.

27. Polydera AC, Stoforos NG \& Taoukis PS (2003). Comparative shelf life study and vitamin $\mathrm{C}$ loss kinetics inpasteurised and high pressure processed reconstituted orange juice. J of Food Engi 5(60): 21-29.

28. Janse GPH (1994). Improving horticultural export performance of developing countries in Asia Rev of Marketing and Agric Eco 62(1): 89-105.

29. Lange DL (2000). New film technologies for horticultural products. J Horti Tech 8(10): 487-490.

30. Mahajan BVC \& Singh R (2014). Effect of packaging films on shelf life and quality of kinnow fruits packed in consumer packages. Inter J of Farm Sci 4(1): 92-98.

31. Min C, Zhang HQ \& Yang HJ (2011). Thermoformed container wall thickness effects on orange juice quality. J. of Food Proc and Preser 8(3/4): 66-71.

32. Minhas AB, Talasila PC \& Cameron AC (2011). An ethanol biosensor can detect lowoxygen injury in modified atmosphere packages of fresh-cut produce. Postharvest Biol Tech 5(15): 127-134.

33. Patel VK, Khimani RA, Patel CR \& Joshi MC (2012). Anti dax kening treatments and packaging on physicochemical changes in whole and sliced fruits on frozen anola cv. Gujarat Anola-l. Asian J of Hort 7(2): 423428. 